\title{
ANALYSIS OF DAMAGE ARISING FROM EXPLOITATION OF THE AIRCRAFT
}

\section{ANALIZA USZKODZEŃ POWSTAJĄCYCH W PROCESIE EKSPLOATACJI STATKÓW POWIETRZNYCH}

\author{
Piotr Woźny ${ }^{1)}$, Józef Blachnio ${ }^{2)}$ \\ ${ }^{1)}$ Wojskowe Zakłady Lotnicze No. 2 S.A.; ${ }^{2)}$ Air Force Institute of Technology \\ e-mail: metrologia@wzl2.mil.pl;jozef.blachnio@itwl.pl
}

\begin{abstract}
During exploitation, due to a variety of reasons, aircrafts are damaged or suffer from different failures. In the process of operation, using appropriate methods of diagnosis, failure, damage, and relative deregulation of individual elements or units can be detected. For this purpose, one can apply a number of indirect diagnostic methods with the use of recorded diagnostic signals or a direct diagnosis with the use of non-destructive methods. The proper identification of the technical condition allows to determine the causes of irregularities and take actions aimed at preventing their occurrence. The article presents the types of exploitation damage of a multi-purpose aircraft. In addition, the criteria for the division of damage and research methods of the causes of damage are presented. Furthermore, an analysis of the scope of activities to be performed during the research of causes of damage to the aircraft is made.
\end{abstract}

Keywords: aircraft, exploitation, damage, diagnostics, research methods

Streszczenie. W trakcie eksploatacji statki powietrzne (SP) z różnych przyczyn ulegaja uszkodzeniom, niesprawnościom badź awariom o różnej postaci. $W$ procesie obstug, wykorzystujac odpowiednie metody diagnozowania, można wykryć awarię, uszkodzenie, względnie rozregulowanie poszczególnych elementów czy zespołów. W tym celu stosuje się szereg pośrednich metod diagnostycznych, wykorzystując zarejestrowane sygnaty diagnostyczne, badź diagnozuje sie w sposób bezpośredni za pomoca metod nieniszczacych. Właściwa identyfikacja stanu technicznego umożliwia ustalenie przyczyn nieprawidłowości i podjęcie przedsięwzięć majacych na celu zapobieżenie ich powstawaniu. W artykule przedstawiono rodzaje eksploatacyjnych uszkodzeń wielozadaniowego statku powietrznego. Dokonano ich analizy (wg różnych kryteriów) i zestawiono $w$ postaci wykreślnych zależności dla poszczególnych zespotów i okresów użytkowania. Ponadto przedstawiono kryteria podziału uszkodzeń, metody badań przyczyn tych uszkodzeń, a także dokonano analizy zakresu czynności, które należy wykonać podczas badań przyczyn uszkodzeń SP.

Stowa kluczowe: statek powietrzny, eksploatacja, uszkodzenie, diagnostyka, metody badań 
Analysis of damage arising from exploitation of the aircraft

Analiza uszkodzeń powstajacych w procesie eksploatacji statków powietrznych

\section{Introduction}

Damage to the aircraft is a destructive event, which involves the change of an aircraft's element from the state of airworthiness to partial airworthiness, and in extreme cases to non-airworthiness. This state arises from exceeding the allowable limits $[1,5,12]$. Damage to the aircraft applies both to the structure of the object, as well as to its individual elements and units. Therefore, damage results in the repair or replacing the element or unit with an airworthy one. The consequence of damage is the failure defined as an adverse event, which occurs in the aircraft technical system, anthropotechnical system: human - aircraft, or sociotechnical: human - aircraft - environment. Thus, airworthiness makes it impossible to physically or contractually fulfil the expected functions [1]. The identification of the causes of damage plays an important role in maintaining a high level of aircraft operation reliability.

The appearance of the damage depends on factors inside the object, the environment, exploitation technology, and operating personnel. Damage is a random process. It is important to determine when the damage occurred, in which period of use. Therefore, it is necessary to base on operating data, e.g. using the reliance of the failure rate during exploitation $\lambda$ (i.e. bathtub curve), resulting from components of the risk of damage to the aircraft elements (Fig. 1) $[4,6,7,11]$. This reliance consists of three phases. The first phase is a phase of initial damage (e.g. run-in phase) - in this phase, the initially significant failure rate decreases rapidly. In the second phase - the normal exploitation period - the failure rate is constant. The third phase - the intensive wear - is characterised by the increasing failure rate. The probability of damage is greater at the beginning of the aircraft exploitation period and after a long period of exploitation or at the end of the service life resource calculated e.g. by the number of operating hours or calendar service life resources. In the first case, errors made at the design and execution stage are revealed, and in the second case, the elements and the entire object wear are disclosed. Both of these factors are random. Damage occurs at a random time (earlier or later) during exploitation. This is governed by the exponential system of such a parameter value that the first phase will be much shorter than the others. The aircraft reliability time usually finishes fast; however, entering the period of normal exploitation is slower. In this phase, we can observe the longest reliable operation time with the lowest probability of damage occurrence. The probability of damage occurrence along with the aircraft exploitation time is slowly growing.

Damage as a random factor, regardless of whether it is the result of human mistakes or whether it was formed as a result of widely understood destructive processes, may lead to failure.

Risk $(R)$ of failure occurrence is the product of the probability of the adverse event occurrence $(P)$ and the measure of its effects $(S)$ [13]:

$$
R=P \times S
$$


According to the course of the failure rate during exploitation $\lambda$, in the final phase of exploitation, the probability of damage increases, thus the risk of damage significantly increases [3]. The probability of damage due to exceeding mechanical, chemical, electrical or thermal strength can be defined as [13]:

$$
P=\int_{0}^{t} \frac{\delta P}{\delta t} d t=\int_{0}^{t} \frac{\delta P}{\delta(\Delta X)}-\frac{\delta(\Delta X)}{\delta t} \delta t
$$

where:

$\Delta X \quad$ - supply of strength (mechanical, chemical, thermal, electrical),

$\frac{\delta P}{\delta(\Delta X)} \quad$ probabilistic strength characteristics of the material,

$\frac{\delta(\Delta X)}{\delta t} \quad$ - speed of changing the supply of strength as a result of the occurring physico-chemical processes inside or the surface of elements,

$t \quad$ - exploitation time.

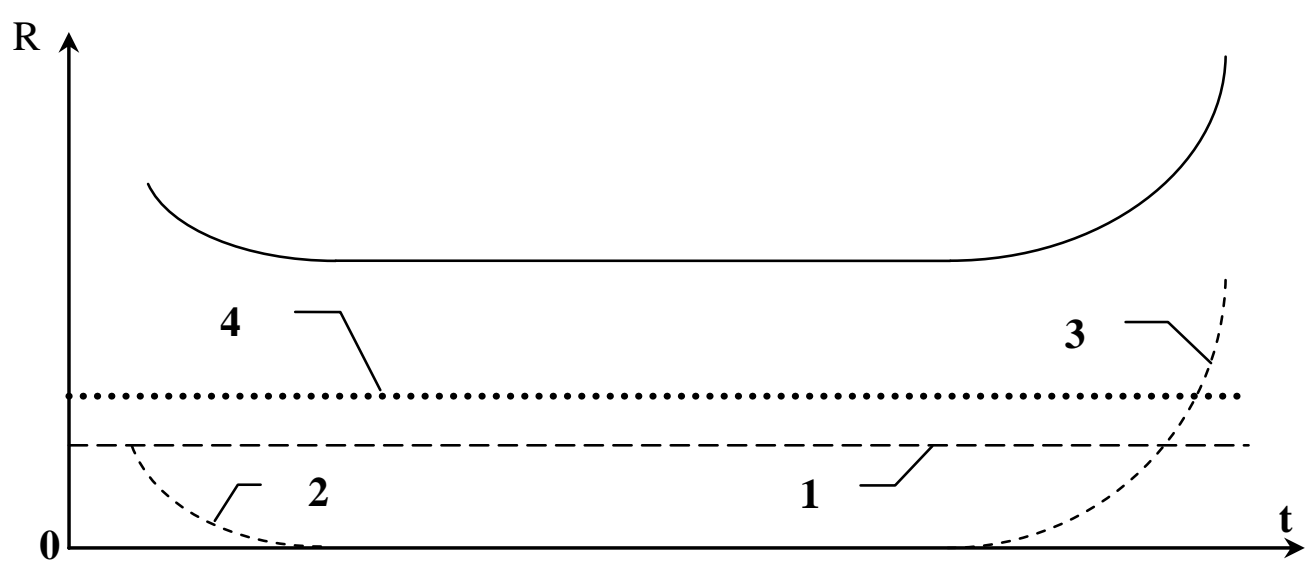

Fig. 1 The components of the risk of damage to the aircraft elements [1]: 1 - component of incidental damage, 2 - component of manufacturing and operation failures, 3 - component of the process of wearing and aging, 4 - component of utility failures

\section{Criteria for the division of aircraft damage}

Aircraft damage is a result of influence of different factors, which can be grouped as follows $[5,8]$ :

- operating - affecting the aircraft as a result of the aircraft task performance,

- external - characterising the impact of the environment on the aircraft,

- anthropotechnical - the human impact on the aircraft.

Furthermore, the factors which cause the formation of damage can be divided into internal - related to the aircraft itself, as well as external - connected with its environment (Fig. 2). 
Analysis of damage arising from exploitation of the aircraft Analiza uszkodzeń powstajacych w procesie eksploatacji statków powietrznych

In the aircraft exploitation system, both controlled and uncontrolled processes, which have an impact on the aircraft destruction rate (Fig. 3), are also performed.

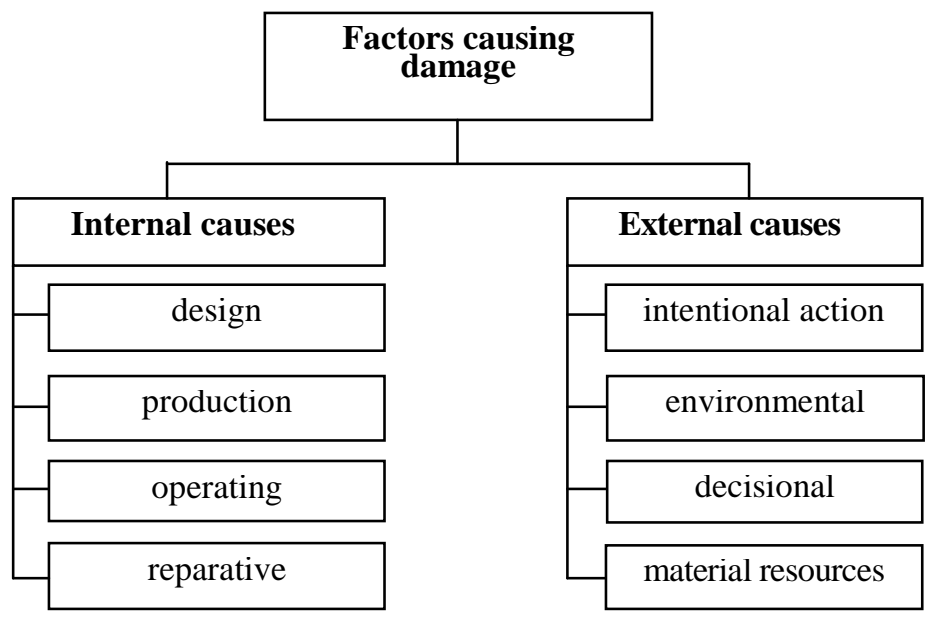

Fig. 2 Factors causing damage [7]

\begin{tabular}{|c|c|}
\hline \multicolumn{2}{|c|}{ MAIN COLLECTIONS OF EXPLOITATION PROCESSES } \\
\hline CONTROLLED PROCESSES & UNCONTROLLED PROCESSES \\
\hline PRE-USE & TRIBOLOGICAL WEAR \\
\hline USE & ADHESIVE WEAR \\
\hline AIRWORTHINESS & OXIDATION \\
\hline POWER & FATIGUE WEAR \\
\hline EXPLOITATION CONTROL & \multirow[b]{2}{*}{ Pitting } \\
\hline \multirow{2}{*}{$\begin{array}{l}\text { Diagnostic } \\
\text { processes }\end{array}$} & \\
\hline & WEAR BY FRETTING \\
\hline Research & WEAR BY SCUFFING \\
\hline \multirow[t]{2}{*}{ LIOUIDATION } & EROSIVE WEAR \\
\hline & CORROSION \\
\hline
\end{tabular}

Fig. 3 Aircraft exploitation processes [1, 5] 
Damage is the most common cause of failure. Other causes include [5]:

- jam, malfunction, disruption of the operation, the lack of power supply of units, systems and devices: electrical, fuel, oil, lubricant and gas,

- a shortage of potential airworthiness related to limiting the operational scope of the element or device,

- malfunction (deregulation) related to the device operation not in accordance with requirements or characteristics,

- etc.

The problems concerning the impact of damage on the aircraft safety are solved by means of the theory of reliability. The aircraft unreliability results from the unreliability of the technical object and human, which is a potential safety risk. Due to very high requirements for the product safety in aviation, the accurate assessment of damage based on the knowledge of the physics of their formation is important (Table 1) $[2,5,10]$.

Table 1. Description of selected types of damage [1,5]

\begin{tabular}{|c|c|}
\hline Type of damage & Description of damage \\
\hline $\begin{array}{ll}\text { Resulting } & \text { from } \\
\text { construction errors } & \end{array}$ & Resulting from design and construction errors \\
\hline $\begin{array}{ll}\text { Resulting } & \text { from } \\
\text { production errors } & \end{array}$ & $\begin{array}{l}\text { Resulting from errors and inaccuracy in the } \\
\text { technological processes or material defects }\end{array}$ \\
\hline $\begin{array}{ll}\text { Resulting } & \text { from } \\
\text { exploitation errors } & \end{array}$ & Resulting from incorrect exploitation \\
\hline $\begin{array}{l}\text { As a result of the process } \\
\text { of wear }\end{array}$ & $\begin{array}{l}\text { As a result of the process of systematic changes in the } \\
\text { physical properties of the system elements }\end{array}$ \\
\hline Initial & $\begin{array}{l}\text { Damage to an element of the system, which was not } \\
\text { directly or indirectly caused by damage to other } \\
\text { elements of the system }\end{array}$ \\
\hline Secondary & $\begin{array}{l}\text { Damage to an element of the system, which was } \\
\text { directly or indirectly caused by damage to other } \\
\text { elements of the system }\end{array}$ \\
\hline Sudden & $\begin{array}{l}\text { Occurring suddenly and not foreseeable in the process } \\
\text { of use and on the basis of operation }\end{array}$ \\
\hline Gradual & Possible to predict on the basis of operation \\
\hline Of the same type & $\begin{array}{l}\text { Damage which from a physical point of view has the } \\
\text { same set of characteristics or the same set of reasons }\end{array}$ \\
\hline Irreversible & $\begin{array}{l}\text { The change of the object from the state of } \\
\text { airworthiness to non-airworthiness, after which it is } \\
\text { impossible to repair the object under certain } \\
\text { conditions }\end{array}$ \\
\hline
\end{tabular}


Analysis of damage arising from exploitation of the aircraft Analiza uszkodzeń powstajacych w procesie eksploatacji statków powietrznych

\begin{tabular}{|l|l|}
\hline Reversible & $\begin{array}{l}\text { The transition of the object from the state of non- } \\
\text { airworthiness, after which it is possible to lead the } \\
\text { object to the state of airworthiness }\end{array}$ \\
\hline Unpredictable & $\begin{array}{l}\text { Damage whose occurrence during use is not taken into } \\
\text { consideration when designing the object }\end{array}$ \\
\hline Predictable & $\begin{array}{l}\text { Natural damage whose occurrence during use is taken } \\
\text { into consideration when designing the object } \\
\text { During the period of preliminary aging, it is mostly an } \\
\text { initial damage }\end{array}$ \\
\hline Catastrophic & $\begin{array}{l}\text { Damage which resulted in losses significantly } \\
\text { exceeding the average value of the losses related to } \\
\text { the object damage }\end{array}$ \\
\hline
\end{tabular}

The most commonly occurring forms of damage are all sorts of cracks, fractures or breaking resulting from exceeding the limit strength of the aircraft element. Mostly, damage to the aircraft in civil aviation is recognised in the drive unit, even up to approx. $40 \%$ (Fig. 4). As much as approx. 30\% of damage arises in elements of the airframe and landing gear. Significant amounts of damage are mainly due to the nature of the mechanical and thermal loads (static, dynamic and congestion) $[1,2,5]$.

The dependence of the occurrence of damage on the phase of flight and type of aircraft - civil, military (Fig. 5), was determined. Damage to civil aircrafts most often occurs during take-off and landing. However, in military aircrafts, damage occurs during the flight, when the crew performs missions, which often leads to significant overload of the airframe and drive structures.

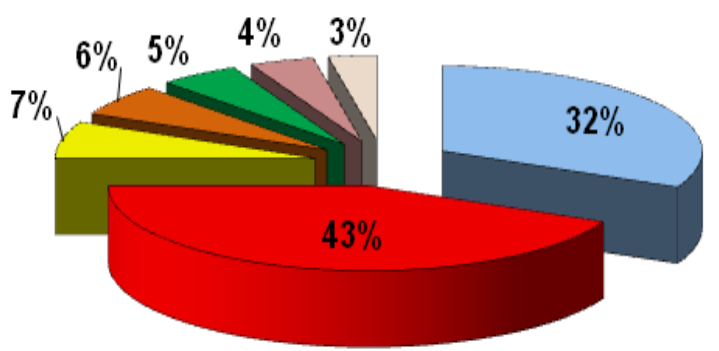
airframe and landing gear
drive and drive control system
landing gear control system
airframe control
pneumatic systems
hydraulic systems
avionic instruments

Fig. 4 The percentage of damage in the division into basic components of the aircraft in civil aviation [2,5] 


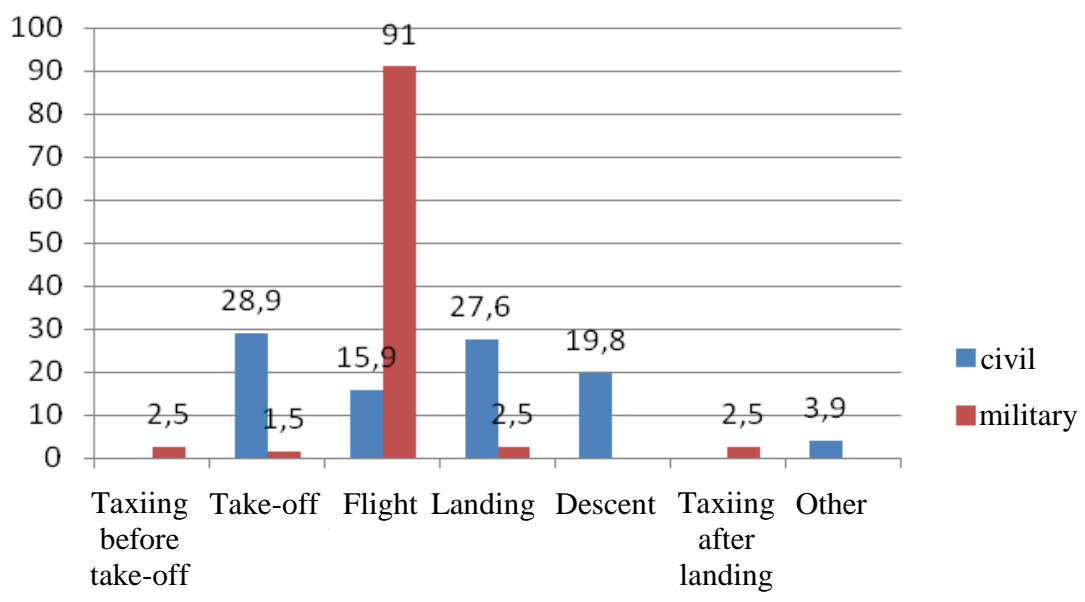

Fig. 5 The percentage of the occurrence of damage in different phases of flight [2,5]

\section{Research methods of causes of the aircraft damage}

In the research of the aircraft damage, depending on consequences, different methods can be used. They can be generally divided into [2]:

1) Methods of empirical research of damage:

- observation,

- measurement,

- comparative,

- experimental.

2) Methods of theoretical research of damage:

- mathematical,

- physical,

- chemical,

- logical,

- other.

Among relatively new methods, using the elements of logic, probability calculus as well as simulation theories which can be used in the research of damage and their consequences, the following methods can be distinguished:

- fault tree,

- Monte Carlo,

- heuristic,

- experts,

- special.

The fault tree method is based on the analysis of the event by presenting the causeeffect chain in the graphical form. In fact, it is a variation of the method developed 
Analysis of damage arising from exploitation of the aircraft Analiza uszkodzeń powstajacych w procesie eksploatacji statków powietrznych

by professor Kaoru Ishikawa of the University of Tokyo. Logical operators are used in construction of the fault tree image. The elementary events, which can be a cause of the considered event being the top of the tree, are the basis of the fault tree. Proper testing algorithm of the damage cause according to this method should be based on three levels (Fig. 6):

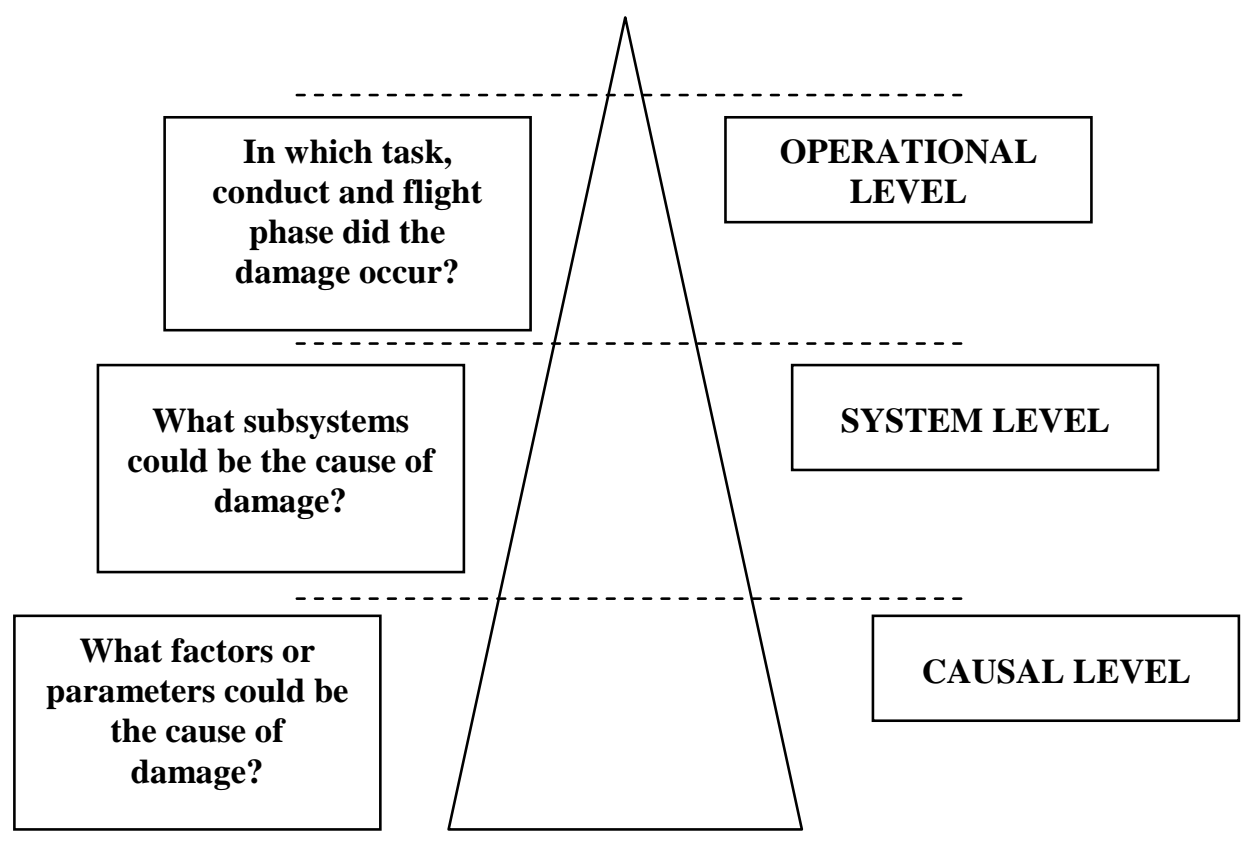

Fig. 6 Levels of building an algorithm of the cause-effect chain [1]

The Monte Carlo method is a method of simulation [3]. It involves the determination of the probability of the event occurrence based on conducted tests. In this method, the greater possibility of occurrence of the event which occurred more frequently in the past is assumed. An example of the action in accordance with assumptions of the Monte Carlo method is the difference in the rate of faults location by an experienced and inexperienced specialist. An experienced specialist estimates the chance of the individual damage occurrence from a set of likely damage in a more accurate manner. Intuitively, based on experience, he or she assesses the chance of damage and makes the averaging operation. The success which consists in reducing the time of the fault location is related to the conscious or unconscious use of the Monte Carlo method. Therefore, the data base related to the occurred damage will constitute a convenience for specialists.

A separate group of methods used to research the causes of damage are heuristic methods $[1,13]$. They are based on the detection of new facts and relationships between them. With the use of these methods, the creative tasks, which can include research on the causes of damage, are resolved. 
The task is considered to be creative when there is no conclusive algorithm to solve it. Heuristic methods are most commonly used in the construction phase of the hypotheses of causes of damage and in setting preventive measures for similar events. Also the heuristic forecasting of events (damage) combines systematic and intuitive thinking. The basic heuristic methods include [3,9]:

- Socratic dialogue,

- task solving seminar,

- pros and cons method,

- morphological method,

- brainstorm,

- system method.

The experts method is another method used to research the causes of damage. It consists in using the knowledge and experience of specialists-experts, who are asked the questions concerning the tested event. Experts make their assessment in isolation from one another at three stages $[1,3]$ :

Stage I - all experts assess the considered phenomenon,

Stage II - experts familiarise themselves with the (anonymous) assessments of other experts,

Stage III - the average value of the assessment of all objects is determined.

The research ends in the case of compliance of all experts' opinions.

Special methods are useful for the research of aircraft damage $[2,5]$. The research of causes affecting the structural change of the aircraft elements, which were subject to long-term and destructive heating, can be an appropriate example. This method uses the phenomenon of the intense coagulation of particles as well as weakening of the heat resistant alloys at the grain boundaries in overheated elements. These changes are visible on micro-sections of the tested samples' sections.

\section{Research of causes of aircraft damage}

Activities related to the research of causes of aircraft damage should be started as soon as possible after its disclosure. The research and analysis of causes require appropriate abilities from a researcher. The main objective is to detect primary (initial) causes, but also other ones which could support damage. In order to make the research objective, the following conditions should be met $[2,5]$ :

a) specialists, who conduct research, should have no links with the occurred damage,

b) every fact related to the circumstances of the damage should be verified in order to confirm its credibility,

c) material evidence should be properly secured,

d) technical and aviation documentation should be carefully examined,

e) proper research, measurement, experiments and analyses should be performed,

f) proposed hypotheses should be verified. 
Analysis of damage arising from exploitation of the aircraft Analiza uszkodzeń powstajacych w procesie eksploatacji statków powietrznych

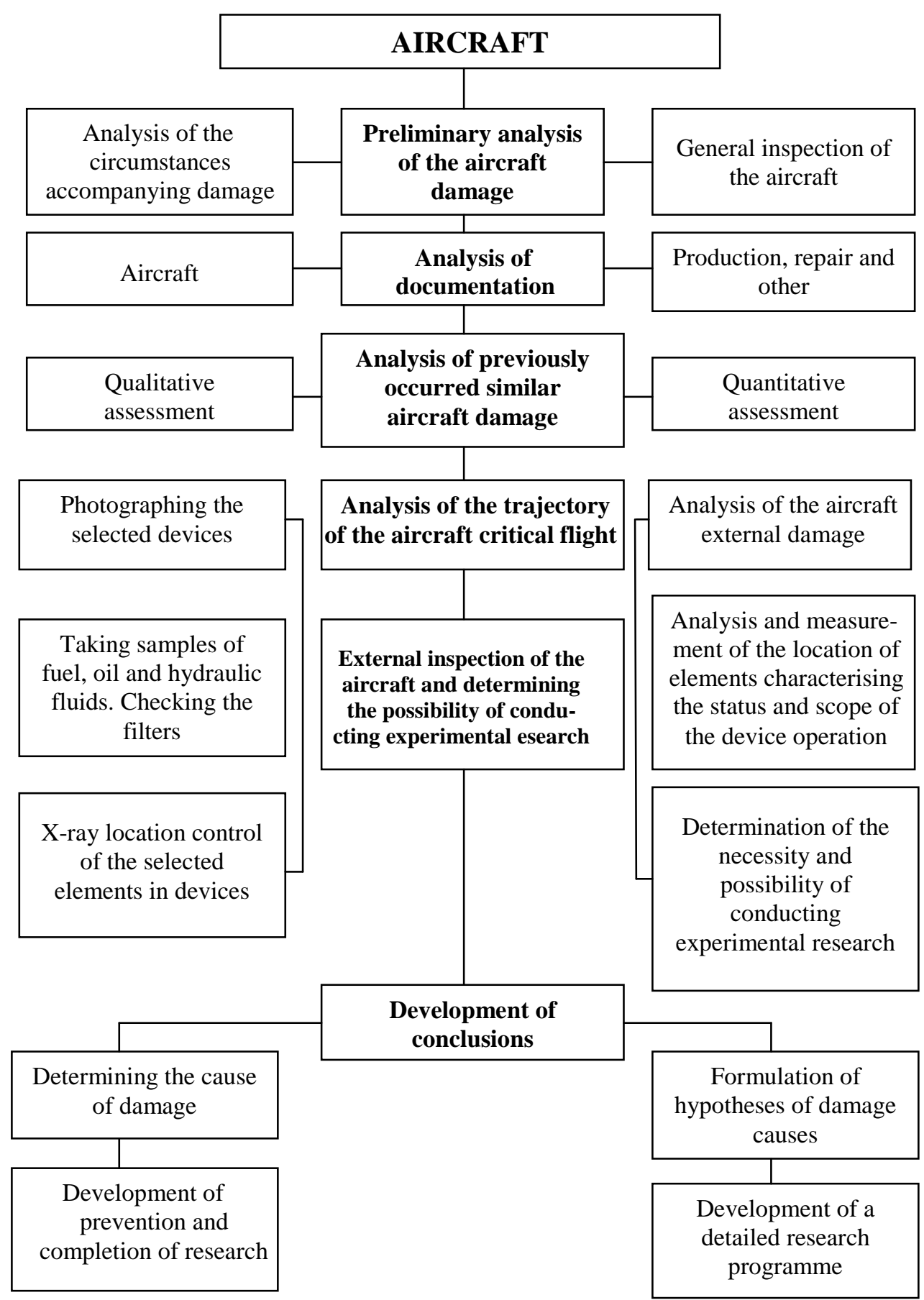

Fig. 8 Research methodology of the aircraft technical condition [2, 5] 
In order to detect causes of the aircraft damage, it is necessary to conduct:

a) the research and analysis of the circumstances of the damage disclosure,

b) the assessment of the quality of use and operation of the aircraft,

c) the research and assessment of the nature of damage to elements, units and structures,

d) the analysis and assessment of the impact of structural and production factors,

e) the assessment of the quality of repair and exploitation services,

f) the assessment of other factors affecting the aircraft reliability.

The scope of the research plan of the cause of damage depends on:
a) the type of damage,
b) the type of the aircraft,
c) the objective of the research,
d) conditions and possibility to perform the research activities,
e) the condition of the tested elements,
f) the degree of identification of other factors that may affect the damage.

The scope of activities to be performed during the research of the damage causes is shown in Fig. 7.

The programme of the research depends on the proposed hypothesis and should determine:
a) the objective of the research,
b) the scope and methods,
c) the execution date,
d) the method of developing and presenting the results,
e) the methodology for verifying hypotheses.

The final stage is the physical representation of the image of damage, the order of the phenomena and damage processes development as well as evidence of the reliability of reasoning.

\section{Conclusion}

During aircraft exploitation, damage is the cause of failures and accidents. It occurs with different intensity in the aircraft structural system. It is mostly caused by processes of wear, aging, fatigue, overheating, etc. The undisclosed ones lead to failures and disasters, causing serious consequences. The effects of damage affect the performance of the aviation task, safety and exploitation costs. The task of the personnel which operates and performs the operation and repair actions is to prevent such a situation. The maintenance of the detailed record and description of disclosed damage provide a basis for preventive and corrective actions, both in the process of exploitation and aircraft design. Preventive actions are broadly defined projects, the aim of which is to prevent the repetition of undesirable phenomena damage. 
Analysis of damage arising from exploitation of the aircraft Analiza uszkodzeń powstajacych w procesie eksploatacji statków powietrznych

Due to a properly developed technical documentation, within the framework of prevention, works aiming to prevent corrosion, excessive wear, deregulation, etc. are conducted. Therefore, the proper prevention based on an analysis of the causes of damage reduces the probability of damage, and thereby increases the safety during the flight.

\section{Bibliography:}

[1] Błachnio J., 1993, Badanie uszkodzeń statków powietrznych powstających $\mathrm{w}$ procesie eksploatacji. Rozdział $\mathrm{w}$ książce redakcji Lewitowicza J., pt. Problemy badań i eksploatacji techniki lotniczej t.2, ITWL, Warszawa. [Research of aircraft damage arising during exploitation. Chapter in the book edited by Lewitowicz J. titled: Problems of research and exploitation of aircraft technology vol.2, ITWL, Warsaw]

[2] Błachnio J., 2007, Metoda badania wypadków lotniczych ze szczególnym uwzględnieniem uszkodzeń statków powietrznych. Kompendium, Seria: PRE - 2/2007, Politechnika Wrocławska. [Method of testing aviation accidents taking into account aircraft damage. Compendium, Series: PRE - 2/2007, Wroctaw University of Technology]

[3] Gercbach I.B., Kordoński Ch.B., 1968, Modele niezawodnościowe obiektów technicznych, Wydawnictwo Naukowo-Techniczne, Warszawa. [Reliability models of technical objects, Science and Technology Publishers, Warsaw]

[4] Iwasiewicz A., 2005, Zarządzanie jakością w przykładach i zadaniach, Śląskie Wydawnictwa Naukowe Wyższej Szkoły Zarządzania i Nauk Społecznych, Tychy. [Quality management in examples and exercises, Silesian Scientific Publishers of the Higher School of Management and Social Sciences, Tychy]

[5] Lewitowicz J., i inni, 2007, Techniczna analiza niesprawności i uszkodzeń. Rozdział w książce redakcji Lewitowicza J., pt.: Podstawy eksploatacji statków powietrznych, t.4, ITWL, Warszawa. [Technical analysis of failures and damage. Chapter in the book edited by Lewitowicz J. titled: Fundamentals of aircraft operation, vol.4, ITWL, Warsaw]

[6] Lewitowicz J., Żurek J., 1990, Problemy eksploatacji statków powietrznych w świetle inżynierii systemów. Materiały IV Szkoły Inżynierii Systemów. Informator ITWL, Lot.Techn.298/90,Warszawa. [Problems of aircraft operation in the light of system engineering. Materials of the IV School of System Engineering. ITWL brochure, Lot. Techn. 298/90, Warsaw]

[7] Łunarski J., 2012, Zarządzanie jakością w przemyśle lotniczym, Praca zbiorowa, Politechnika Rzeszowska. [Quality management in the aviation industry, Collective work, Rzeszów University of Technology]

[8] Muślewski Ł., 2010, Podstawy efektywności działania systemów transportowych, ITE-PIB, Bydgoszcz-Radom. [Fundamentals of effectiveness of transportation systems functioning. The Institute for Sustainable Technologies - National Research Institute, Bydgoszcz-Radom] 
[9] Osińska M., 2012, Prognozowanie w logistyce, Wyższa Szkoła Gospodarki, Bydgoszcz. [Forecasting in logistics, University of Economy, Bydgoszcz]

[10] Woropay M., 1996, Podstawy racjonalnej eksploatacji maszyn, Praca zbiorowa, ITeE, Radom. [Basics of reasonable machine operation, Collective work. The Institute for Sustainable Technologies, Radom]

[11] Woropay M., Muślewski Ł., 2005, Jakość w ujęciu systemowym, ITE-PIB, Radom. [Quality in a systemic perspective. The Institute for Sustainable Technologies - National Research Institute, Radom]

[12] Woropay M., Wdzięczny A., Bojar P., Szubartowski M., 2008, Metoda oceny wpływu skuteczności realizowanych napraw na niezawodność i bezpieczeństwo działania systemów transportu miejskiego, ITeE, Radom. [Method of assessment of the impact of effectiveness of carried out repairs on reliability and safety of public transport system functioning. The Institute for Sustainable Technologies, Radom]

[13] Соломонов П.А. 1977, Безотказность авиационной техники и безопасность полетов. Транспорт. Москва.

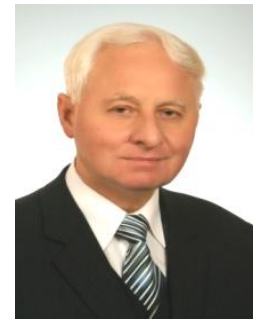

Prof. Józef Btachnio, Ph.D. Eng. is a researcher at the Air Force Institute of Technology and the Biatystok University of Technology. He has qualifications of the Ministry of Science and Higher Education in: aviation, aerospace, material engineering as well as machine construction and operation.

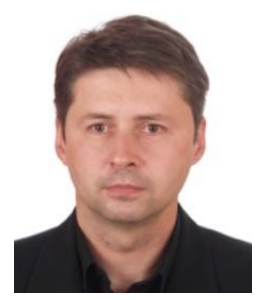

Piotr Woźny, M.Sc., is a specialist in metrology in Wojskowe Zaktady Lotnicze No. 2 S.A. in Bydgoszcz. His area of interest is measuring diagnostic methods in the process of aircraft repair and services as well as the quality of measurements in the exploitation processes. 
Analysis of damage arising from exploitation of the aircraft Analiza uszkodzeń powstajacych w procesie eksploatacji statków powietrznych 